\title{
Origin of Little Missouri River - South Fork Grand River and nearby Drainage Divides in Harding County, South Dakota and Adjacent Eastern Montana, USA
}

\author{
Eric Clausen \\ Independent Researcher, Jenkintown, PA, USA \\ Email: eric2clausen@gmail.com
}

How to cite this paper: Clausen, E. (2017) Origin of Little Missouri River - South Fork Grand River and nearby Drainage Divides in Harding County, South Dakota and Adjacent Eastern Montana, USA. Open Journal of Geology, 7, 1063-1077. https://doi.org/10.4236/ojg.2017.78071

Received: July 11, 2017

Accepted: August 4, 2017

Published: August 7, 2017

Copyright $\odot 2017$ by author and Scientific Research Publishing Inc. This work is licensed under the Creative Commons Attribution International License (CC BY 4.0).

http://creativecommons.org/licenses/by/4.0/ (c) (i) Open Access

\begin{abstract}
Barbed tributaries flowing in southeast directions, an asymmetric drainage divide with both the South Fork Grand River and the North Fork Moreau River, and the Jump-off escarpment-surrounded basin (interpreted here to be a large abandoned headcut) are examples of topographic map evidence suggesting the north oriented Little Missouri River valley eroded headward across a large southeast oriented anastomosing complex of ice-marginal melt water flood flow channels that once crossed Harding County, South Dakota. Additional evidence includes southeast oriented tributaries to the northeast oriented South Fork Grand River and multiple divide crossings (e.g. through valleys and wind gaps) on the Boxelder Creek-Little Missouri River divide (in eastern Montana and west of the Little Missouri River) and suggests deep regional erosion occurred as the north oriented Little Missouri River valley eroded headward into and across the region. Harding County is located south and west of the southwest limit of coarse-grained glacial erratic material and icemarginal melt water flow routes logically should have crossed it. Deep melt water erosion of Harding County and adjacent eastern Montana regions to the west is not consistent with many previous drainage history and glacial history interpretations, but is consistent with deep erosion by continental ice sheets.
\end{abstract}

\section{Keywords}

Boxelder Creek, Carter County (Montana), Deep Melt Water Erosion, Drainage Divide, Moreau River, Powder River

\section{Introduction}

Harding County is located in South Dakota's extreme northwest corner with 
eastern Montana immediately to the west and the North Dakota southwest corner immediately to the north. The Little Missouri River as seen in Figure 1 originates in northeast Wyoming along the Black Hills northwest flank and then flows in a northeast direction across southeast Montana before entering Harding County, South Dakota where it turns to flow in a north direction to enter southwest North Dakota. In west central North Dakota the Little Missouri River turns in an east direction to reach an east oriented Missouri River segment upstream from where the Missouri turns to flow in a south direction. Headwaters of southeast and east oriented Missouri River tributaries are found just east of the north oriented Little Missouri River in both southwest North Dakota and northwest South Dakota. The asymmetric drainage divide between the north oriented Little Missouri River and southeast and east oriented Missouri River tributaries suggests headward erosion of the north oriented Little Missouri River valley was across a southeast or east oriented drainage system. In North Dakota it is possible to stand on this asymmetric divide and look east across gently sloping grass covered plains draining to the Missouri River and then turn to look west down steep slopes leading to the deep Little Missouri River badlands, which are carved into the Little Missouri River valley walls.

To the south the situation is almost the reverse. Winchester et al. [1] describe the asymmetric Little Missouri-South Fork Grand River divide as follows: "To the west the land is rolling and grass covered, but to the east, for 2 or 3 miles, the area is deeply dissected into pronounced badlands, locally known as the Jump-off'. At its south end the Jump-off also "marks the north side of the divide between

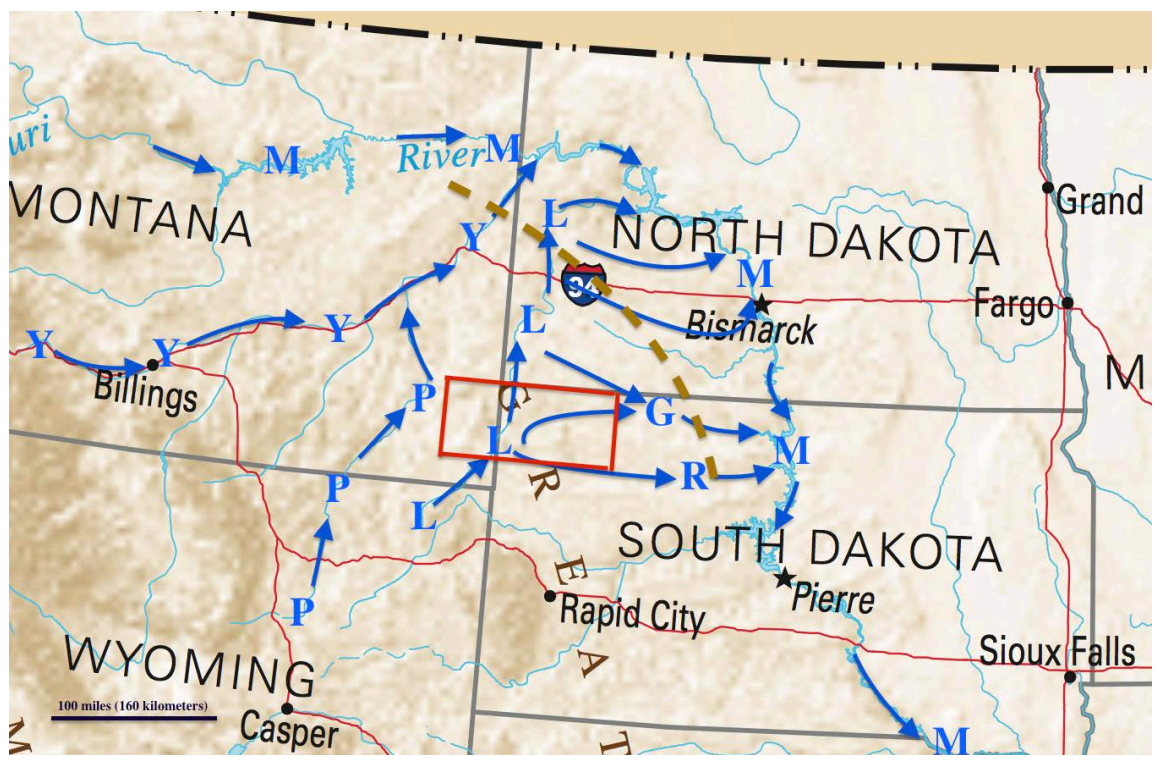

Figure 1. Modified map from USGS National Map website showing the study region (red rectangle). Blue arrows and letters identify drainage routes as follows: "L" Little Missouri River, "M" Missouri River, "Y” Yellowstone River, "P” Powder River, "G” Grand River, and "R" Moreau River. Dashed brown line marks the approximate southwest limit of coarse-grained glacial erratic material (fine grained till is abundantly found north and east of the Missouri River). 
the Moreau River and the South Fork of the Grand River... At many places along the northeast side of the divide there is a precipitous scarp with steep ridges and bare 'mud' buttes carved in the soft shale." The Jump-off forms a semi-circular escarpment that according to Baker [2] is "encroaching on the higher Little Missouri River basin with steep-sided head gullies cutting back into the smooth [upland] surface." To the east of the Jump-off escarpment the topography "generally flattens out within half a mile into the old age plain of the South Fork" Grand River valley, which Baker suggests correlates with an old age pre-glacial erosion surface found further to the east. Baker [2] describes the Little Missouri River basin in most of Harding County as still being in the old stage while north of the North Dakota border headward erosion of a much deeper Little Missouri River valley from the deep Missouri River valley since glaciation has initiated a new erosion cycle.

Topography in much of western North Dakota is consistent with an interpretation that the north oriented Little Missouri River valley eroded headward across east or southeast oriented drainage. However, Baker's [2] description of the semi-circular Jump-off escarpment in northwest South Dakota implies headward erosion by the east oriented South Fork Grand River (and Moreau River) is eroding the north oriented Little Missouri River drainage basin. Winchester et al. [1] support the implication by stating, "The waters that flow eastward in western South Dakota have a much shorter course to the Gulf of Mexico than those which flow by way of the Little Missouri River; in fact, the distance from western Harding County down the Little Missouri and Missouri Rivers to Fort Pierre, South Dakota is nearly twice as great as the distance by way of the Grand River." Added to these observations is the commonly made suggestion that coarse-grained alluvium found at isolated locations along or near the asymmetric Little Missouri-Missouri River drainage divide had a Black Hills source. Fossils found in those discontinuous deposits have been correlated with Oligocene White River Formation sediments found in the South Dakota Badlands located east of the Black Hills (e.g. Lillegraven [3] and Clark [4]). Multiple researchers have used these interpretations to suggest an Oligocene north flowing river deposited the sedimentary material. For example Quirke [5] in his discussion of sediments found in the North Dakota Killdeer Mountains (north of Dickinson, North Dakota) states, "The upper strata of the mountains are correlated with the White River formation. This extends considerably the known distribution of the Oligocene series. Study of the formation leads to the conclusion that ... most of the rocks were laid down in a lake. The lake was fed by a river flowing northward from the Black Hills...”

Considerable literature implies and even states that a north oriented river along or near the present day Little Missouri River alignment developed during Oligocene or even earlier time, however there also is literature describing Harding County evidence for mid Tertiary and pre Little Missouri River southeast oriented drainage. Toepelman [6] in an unpublished University of Chicago 
Ph.D. thesis (supervised by J Harlan Bretz) described evidence at Slim Buttes (location 1 in Figure 2) for post-Oligocene or pre-Miocene slumping along deep southeast oriented river valleys. In a study of heavy minerals Malhotra and Teglund [7] rejected a Black Hills source area for sediments at Slim Buttes found in what they described as a new formation immediately below the White River Formation and suggested cross bedding in those sediments indicated deposition by a southeast oriented river or stream. Gill [8] mapped landslide blocks of latest Oligocene or earliest Miocene age along deep northwest to southeast trending valleys at Slim Buttes and also at the Jump-off and in the Short Pine Hills in Harding County (location 2 in Figure 2) and the Long Pine Hills in Carter County, Montana (location 3 in Figure 2). Gill states, "After Brule [a White River Formation member] deposition, streams cut through several hundred feet of Oligocene and older rocks. ...The accumulated evidence indicates that the streams developed deep, steep-sided valleys aligned to the northwest... Along streams, the Brule cap rock formed nearly vertical upper valley walls above steep valley slopes in the softer rocks of the underlying Chadron [another White River Formation member] and older formations. Over steepening of the lower valley slopes resulted in slope instability and... large blocks of rocks from the valley walls moved downward and outward onto the valley floor."

Lillegraven [3] without addressing evidence that Gill had mapped at the Jump-off or in the Short and Long Pine Hills rejected the hypothesis that "structural complexities in the latest Oligocene or earliest Miocene at Slim Butte" were due "to slumping or landsliding of strata into stream-carved valleys or from escarpment faces." Among reasons cited was "the absence of evidence

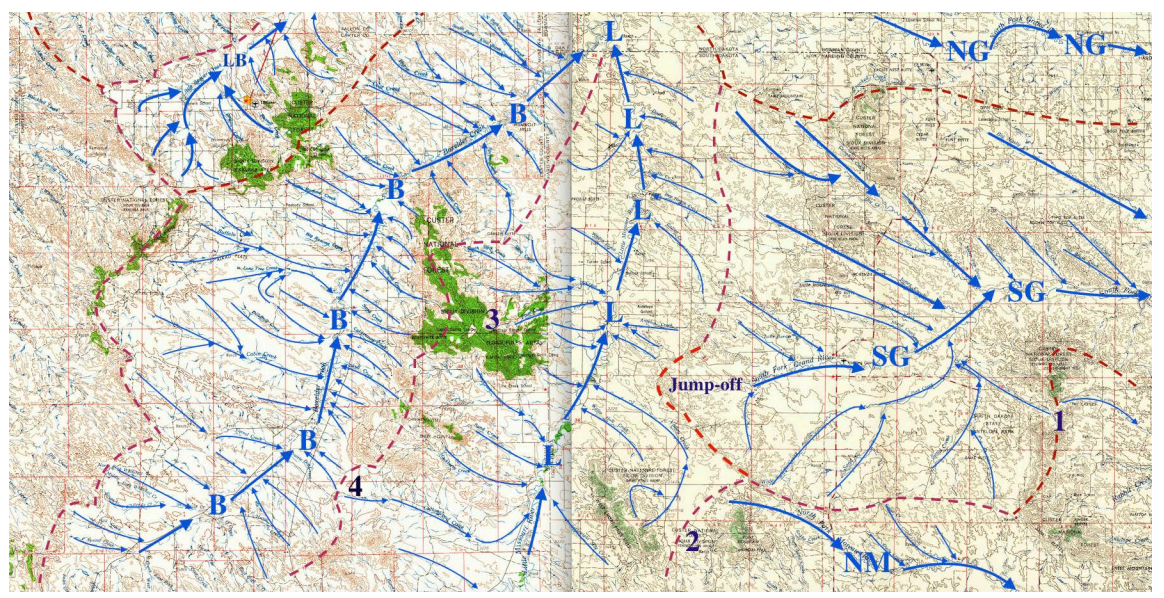

Figure 2. Modified sections of USGS Lemmon SD (east) and Ekalaka MT (west) 1: 250,000 scale topographic maps. Blue arrows and letters identify major drainage routes as follows: "L" Little Missouri River, "B" Boxelder Creek, "LB" Little Beaver Creek, "SG" South Fork Grand River, "NG" North Fork Grand River, and "NM" North Fork Moreau River. Dashed red lines follow major drainage divides with the edge of the east wall of the north oriented Powder River valley located along the figure west edge. The contour interval is 100 feet (30.5 meters). Squares outlined by the faint red grid are six miles ( $9.7 \mathrm{ki}$ lometers) across. 
for a major river in latest Oligocene or earliest Miocene time-a river of sufficient size to carve canyons that allow slumping." Clark [4] included a map showing the White River Formation sediments at Slim Buttes to have been derived from Black Hills source areas and ignored the previously published evidence describing Mid Tertiary southeast oriented drainage across Harding County. More recently Clausen [9] reported small rounded boulders and large cobbles in talus associated with the Gill's mapped slump and landslide blocks at Slim Buttes, the Jump-off, and the Short Pine Hills that suggested a high energy river or rivers had flowed across region. Further north in the North Dakota White River sediments (located east of the deep north oriented Little Missouri River valley) Clausen [9] found distinctive alluvium that could be traced across the Little Missouri-Yellowstone River divide and then headward along the northeast oriented Yellowstone River to mountain sources upstream from Billings, Montana.

While not reported in Clausen's 1989 paper [9] a trail of this distinctive alluvium also leads from southwest North Dakota White River Formation deposits in a southeast direction across the Grand River valley (east of Slim Buttes) and then across the Grand-Moreau River drainage divide and into the Moreau River valley. The southeast oriented distinctive alluvium trail is slightly south and west of the mapped southwest margin of glacial erratic material (as mapped by Clayton on the 1980 North Dakota geologic map [10]), which is generally about 100$\mathrm{km}$ south and west of the Missouri River. The trail may represent the location of a former southeast oriented ice-marginal melt water river. If so the southeastoriented ice marginal river crossed what are today deep north oriented Yellowstone, Little Missouri, and other river valleys. Ice-dammed glacial lakes are sometimes thought to have filled those valleys although large southeast or north oriented delta deposits in the hypothesized lake basins have never been mapped, otherwise reported, or found by this author. Without such evidence there is good reason to believe the north oriented Little Missouri River in Harding County and western North Dakota and the north oriented Yellowstone and Powder Rivers to the west did not exist at that time. If so, an analysis of drainage divide evidence along the asymmetric Little Missouri-South Fork Grand River drainage divide (including the Jump-off escarpment rim) may provide clues as to how the north oriented Little Missouri River drainage route evolved.

\section{Research Method}

The Jump-off was one of many intriguing landforms observed during the author's much larger and unpublished Missouri River drainage basin landform origins research project. The Missouri River flows to the Mississippi River and drains much of the north central United States including most northern Great Plains and Rocky Mountain areas located to the east of the North American east-west continental divide and also small areas in the provinces of Alberta and Saskatchewan. The multi-year Missouri River drainage basin landforms origins 
research project consisted of systematically studying detailed topographic maps of the entire Missouri River drainage basin and adjacent drainage basins to determine how major drainage divides within and surrounding the large and complex Missouri River drainage basin originated. Drainage divide origins were determined by using divide crossings (through valleys, wind gaps, etc.) as evidence of previous drainage routes and then using barbed tributaries, elbows of capture, asymmetric drainage divides, and similar evidence to determine how many thousands of capture events altered earlier drainage routes so as to produce Missouri River drainage basin drainage routes that exist today. Approximately 550 unpublished and detailed project essays (or research notes) can be found in blog format on the author's geomorphologyresearch.com website.

Maps used in the study reported here were obtained from the United State Geological Survey (USGS) National Map website [11] and the Historical Map Collection website [12]. Research pertinent to this paper began by assuming ice-marginal melt water probably flowed in a southwest direction across Harding County at the time a continental ice sheet's southwest margin was at the present day southwest limit of mapped glacial erratic material (shown by the brown dashed line in Figure 1). The question was asked how would large volumes of southeast oriented melt water erode the study region landscape? At such a time the ice sheet margin would have forced ice-marginal melt water to spill across previously formed drainage divides and to carve an anastomosing complex of new valleys as the water flowed in a southeast direction. Erosion resistant rock now caps study region buttes, but easy to erode claystone is the predominant bedrock elsewhere and the question was asked how would southeast oriented floodwater spilling across drainage divides erode such a region. Baker [13] describes the catastrophic flood eroded Channeled Scablands of Washington State as having been eroded by anastomosing flood flow channels. He states, "anastomosis occurs in the Channeled Scabland because pre-flood valleys did not have the capacity to convey the Missoula Flood discharges without spilling over pre-flood divides into adjacent valleys. This crossing of divides produces the effect of channels dividing and rejoining." Based on this definition a decision was made to look for topographic map evidence of a former southeast oriented anastomosing channel complex.

The north oriented Little Missouri River and east oriented Grand and Moreau Rivers today flow from non-glaciated regions into glaciated regions and their valleys are not oriented along routes the southeast oriented ice-marginal melt water would have flowed. However headward erosion of those river valleys could have been across a massive southeast oriented ice-marginal anastomosing channel complex as the ice-marginal melt water flowed across the region. If so drainage divides on either side of the north oriented Little Missouri River should show evidence of having been crossed by multiple southeast oriented channels. Such evidence as seen on topographic maps would be in the form of multiple divide crossings (e.g. through valleys, wind gaps, saddles, etc.) and southeast or northwest orientations of streams originating near those divide crossings. To test 
this hypothesis the Little Missouri-South Fork Grand River drainage divide and the Boxelder Creek-Little Missouri River drainage divide to the west were studied on detailed topographic maps to determine orientations of tributary streams originating on or near those divides and to look for evidence of a former southeast oriented anastomosing channel complex and of other possible flood eroded landforms. Map evidence for the Jump-off escarpment-surrounded basin was specifically investigated in detail to determine the escarpment origin. Map evidence for additional nearby drainage divides was also analyzed to determine if their origin was consistent with origins determined for the Little MissouriSouth Fork Grand River and Boxelder Creek-Little Missouri River divides. A summary of results from the above mentioned topographic map studies follows.

\section{Study Region Drainage Divides}

\subsection{Little Missouri-South Fork Grand River Drainage Divide}

Figure 2 shows the asymmetric Little Missouri-South Fork Grand River divide and also a section of the Little Missouri-North Fork Moreau River drainage divide along with the North Fork-South Fork Grand River divide and several divides further to the west. Note short northwest oriented tributaries draining to the north oriented Little Missouri River and how north of the Jump-off much longer southeast oriented tributaries drain to the northeast and east oriented South Fork Grand River. Also note how the South Fork Grand-North Fork Moreau River divide follows the Jump-off's northeast-facing escarpment rim and how North Fork Moreau River headwaters are oriented in a southeast direction. These tributary orientations can be easily explained by headward erosion of the north oriented Little Missouri River valley across multiple southeast oriented flood flow channels such as would be found in large complex of southeast oriented anastomosing flood flow channels. The short northwest oriented Little Missouri River tributaries were developed by reversed flow on northwest ends of beheaded southeast oriented flood flow channels with the longer southeast oriented South Fork Grand River tributaries forming along downstream routes of the beheaded flood flow channels. Further evidence supporting this interpretation is found in the numerous southeast oriented tributaries that are shown to be joining the north oriented Little Missouri River as barbed tributaries.

East of the Jump-off escarpment some of the South Fork Grand River headwaters streams in the southern half of the semi-circular Jump-off escarpmentsurrounded basin are oriented in north and northeast directions even though short northwest oriented Little Missouri River tributaries drain the region immediately to the west of the escarpment rim. These north and northeast oriented South Fork Grand River headwaters streams and the northeast and east oriented South Fork Grand River segments seen in Figure 2 are not consistent with the northwest and southeast orientation of most other study region tributary streams nor with the direction of the hypothesized melt water formed southeast oriented anastomosing channel complex. Understanding this anomalous evi- 
dence requires a better understanding of the Jump-off escarpment-surrounded basin and its origin. Figure 3 has enlarged the Jump-off semi-circular escarpment surrounded basin area seen in Figure 2. The black and brown dashed line follows the Jump-off escarpment rim and also marks the South Fork Grand River drainage divide. Note how much of the Jump-off escarpment rim is actually a ridge separating the South Fork Grand River drainage basin from the Little Missouri River drainage basin with the Little Missouri River tributary valley floor elevations being generally 100 - 200 feet (30.5 - 61 meters) higher than nearby South Fork Grand River tributary valley floor elevations.

No recent literature was found in which the Jump-off erosion history was specifically discussed, however the semi-circular escarpment-surrounded basin enclosed by the Jump-off is similar in shape and size to a number of other North American Great Plains and Rocky Mountain escarpment surrounded basins. Examples of such escarpment-surrounded basins can be found in North Dakota north of Dickinson (east of the north oriented Little Missouri River), in eastern Wyoming and western Nebraska (east of the Laramie Range and north oriented Chugwater Creek) and east of the Black Hills and the northeast oriented Cheyenne River (east of Rapid City, South Dakota).

These and other similar escarpment-surrounded basins have several common characteristics including no visible surface water drainage leading to them and a deep valley that today cuts directly across the route surface water would have had to use to reach the escarpment-surrounded basin. These considerations have caused many previous investigators to suggest that surface water did not erode

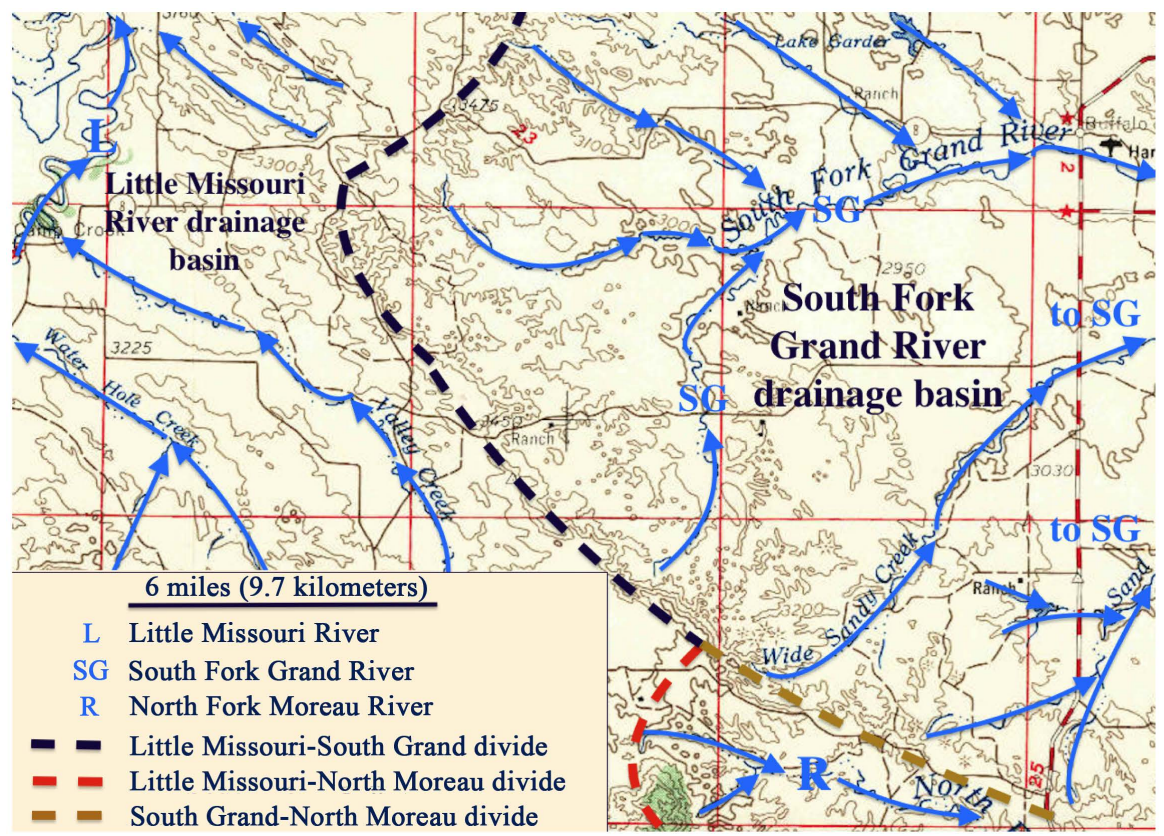

Figure 3. The Jump-off escarpment-surrounded basin as observed on an enlarged and modified section of the USGS 1:250,000-scale Lemmon, SD topographic map. Dashed lines, arrows and letters identify drainage divides and routes. The map contour interval is 100 feet (30.5 meters). 
such basins. Instead spring sapping and groundwater seepage are often claimed to be the primary agent responsible for eroding such basins (e.g. see Higgins [14]). Springs are located along the Jump-off escarpment wall and other water seepage does occur. However spring sapping and water seepage do not explain the Jump-off escarpment-surrounded basin size, shape, or orientation nor do they explain any of the regional drainage route orientations or the ridge along the Jump-off escarpment rim.

If spring sapping and water seepage did not erode the Jump-off escarpmentsurrounded basin then something else did. Clausen [15] has recently suggested that the Scenic and Sage Creek escarpment-surrounded basins in the South Dakota Badlands are today large abandoned southeast-oriented head cuts that had been eroded headward from the wall of the deep northeast and east oriented White River valley by massive southeast oriented flood flow. Headward erosion of the Scenic and Sage Creek Basin head cuts abruptly ceased when headward erosion of the deep northeast oriented Cheyenne River valley captured the southeast oriented flood flow. A similar sequence of events probably explains erosion of the Jump-off escarpment-surrounded basin. Headward erosion of the deep northeast oriented South Fork Grand River valley began to capture southeast oriented flood flow that was moving to the previously eroded North Fork Moreau River valley. Note in Figure 2 and Figure 3 how the North Fork Moreau River today begins as a southeast oriented stream on the Jump-off escarpment rim and how a northwest oriented Little Missouri River tributary drains the rim region immediately to the northwest of the North Fork Moreau River headwaters. This evidence suggests the Jump-off escarpment-surrounded basin eroded headward as a southeast-facing head cut from a deep northeast oriented South Fork Grand River valley. Erosion of the southeast-oriented head cut ceased when headward erosion of the north oriented Little Missouri River valley captured the southeast oriented flood flow leaving the Jump-off escarpment-surrounded basin as a large abandoned headcut, similar to the Scenic and Sage Creek Basins. Headward erosion of the Little Missouri River valley also caused reversals of flow in beheaded southeast oriented channels to create the short northwest oriented Little Missouri river tributaries found immediately to the west of the Jump-off escarpment rim.

\subsection{Boxelder Creek-Little Missouri River and Other Figure 2 Divides}

Boxelder Creek is a northeast oriented Little Missouri River tributary joining the Little Missouri River just north of the North Dakota border (see Figure 2). The Boxelder Creek-Little Missouri River divide is a discontinuous ridge drained by numerous southeast-oriented Little Missouri River and northwest oriented Boxelder Creek tributaries. Through valleys, wind gaps, and other low points notched into the divide link opposing southeast and northwest oriented drainage routes. Most through valleys, wind gaps, and low points linking the southeast and northwest oriented tributaries are best seen on detailed topographic maps, 
however a major through valley is found at location 4 (in Figure 2) and is now drained by southeast oriented Cottonwood Creek and northwest oriented Boxelder Creek tributaries. Note how Cottonwood Creek turns to flow in a northeast direction before joining the north oriented Little Missouri River. The through valleys, wind gaps, and other low points linking the southeast oriented Little Missouri River tributaries with opposing northwest oriented Boxelder Creek tributaries provide excellent evidence that numerous and closely spaced southeast oriented channels, such as might be found in a large anastomosing channel complex, once crossed the entire region.

The southeast oriented water must have originally flowed on a surface as high as the highest points along the Boxelder Creek-Little Missouri River divide today, which means the deep north oriented Powder River valley (located along the west edge of Figure 2) did not exist at that time. Southeast oriented flood water must have deeply eroded the region as it first flowed to the North Fork Moreau River valley and then was captured in succession by headward erosion of the northeast oriented South Fork Grand River valley, the north oriented Little Missouri River valley, the northeast oriented Boxelder Creek valley, the northeast oriented Little Beaver Creek valley, and the much deeper north oriented Powder River valley. Note how northeast oriented Boxelder Creek, like the north oriented Little Missouri River, is joined by numerous southeast oriented barbed tributaries. These southeast oriented tributaries also provide excellent evidence that the northeast oriented Boxelder Creek valley eroded headward across multiple southeast oriented flow channels such as might be found in a large southeast oriented anastomosing channel complex. Further note the asymmetric drainage divide between northeast-oriented Boxelder Creek and the Powder River where northwest oriented Powder River tributaries originate near headwaters of southeast oriented Boxelder Creek tributaries. Drainage routes in the Figure 2 map area only make sense in the context of headward erosion of a succession of deep northeast and north oriented valleys across a large flood formed southeast oriented anastomosing channel complex.

In addition to the Boxelder Creek-Little Missouri River divide other major drainage divides illustrated in Figure 2 include the North Fork Grand-South Fork Grand River divide, Little Beaver-Boxelder Creek divide, Powder RiverBoxelder Creek divide, Powder River-Little Beaver Creek divide, O’Fallon-Little Beaver Creek divide, and Powder River-O'Fallon Creek divide. Note in Figure 2 how headward erosion of the North Fork Grand River valley beheaded southeast oriented flood flow routes to the newly eroded South Fork Grand River valley. The North Fork Grand River drainage basin first beheaded southeast oriented flood flow flowing to the South Fork Grand River. Headward erosion of the north oriented Little Missouri River valley next beheaded all southeast oriented flood flow in succession to the North Fork Grand River valley, South Fork Grand River valley, and North Fork Moreau River valley establishing present day drainage routes in the region located east of the north oriented Little Missouri 
River.

Little Beaver Creek is a northeast oriented Little Missouri River tributary and the Little Beaver-Boxelder Creek divide like the Boxelder Creek-Little Missouri River divide is drained by southeast oriented (and barbed) Boxelder Creek tributaries and northwest oriented Little Beaver Creek tributaries. Through valleys, wind gaps, and other low areas are notched into the Little Beaver-Boxelder Creek divide and link the opposing southeast and northwest oriented tributary stream valleys. Like with the Boxelder Creek-Little Missouri River divide, the through valleys, wind gaps, and other low areas suggest that before headward erosion of the deep northeast oriented Boxelder Creek valley closely spaced southeast oriented flow channels crossed what is now the Little Beaver-Boxelder Creek divide. Headward erosion of the deep northeast oriented Little Beaver Creek valley beheaded in sequence from the northeast to the southwest the southeast oriented flow channels causing water on northwest ends of the beheaded channels to flow in a reverse direction and to initiate what are today northwest oriented Little Beaver Creek tributaries and to create the Little Beaver-Boxelder Creek divide.

Looking at Figure 2 it is difficult to imagine headward erosion of a deep northeast oriented Little Beaver Creek valley into a surface at least as high as highest points on the Little Beaver-Boxelder Creek divide because today the area immediately northwest of northeast oriented Little Beaver Creek is a steep northwest-facing escarpment leading to O'Fallon Creek (not seen in figures shown in this paper), which flows in a north and then northwest direction to reach the northeast oriented Yellowstone River. Headward erosion of the deep north and northwest oriented O'Fallon Creek valley (from the deep northeast oriented Yellowstone River valley) almost completely removed the Little Beaver Creek drainage basin's northwest side leaving today a remarkable asymmetric divide where northeast oriented Little Beaver Creek flows along the rim of the northwest-facing escarpment with the floor of the deep O'Fallon Creek valley (just north of Figure 2) being more than 400 feet (122 meters) lower than the Little Beaver Creek valley floor. The asymmetric O'Fallon-Little Beaver Creek divide provides strong evidence that headward erosion of the deep north and northwest oriented O'Fallon Creek valley occurred after headward erosion of the northeast oriented Little Beaver Creek valley.

Following headward erosion of the deep north and northwest oriented O'Fallon Creek valley (from the northeast oriented Yellowstone River valley) headward erosion of the deep and northeast oriented Yellowstone River valley seen in Figure 1 and its tributary north oriented Powder River valley beheaded all southeast oriented flood flow moving into what was then the newly eroded O'Fallon Creek valley and to the western end of the Little Beaver Creek drainage basin and the upstream Boxelder Creek drainage basin to create the Powder River-O'Fallon Creek, Powder River-Little Beaver Creek, and Powder River-Boxelder Creek drainage divides seen in Figure 2. Headward erosion of the deep O'Fallon Creek and the even deeper Yellowstone-Powder River valleys oc- 
curred in the same progressive sequence from the southeast to the northwest that was seen with North Fork Moreau River, South Fork Grand River, North Fork Grand River, Little Missouri River, Boxelder Creek, and Little Beaver Creek valleys. This remarkable sequence of valley formation is consistent with headward erosion of deep valleys across massive southeast oriented ice-marginal melt water flood flow and explains almost all, if not all, drainage systems and erosional landforms seen on the detailed regional topographic maps and also documents deep erosion of the entire study region.

\section{Discussion and Conclusions}

Southeast oriented ice-marginal melt water almost certainly deeply eroded Harding County, South Dakota and adjacent eastern Montana regions. Highest Boxelder Creek-Little Missouri River drainage divide elevations (in the Long Pine Hills at location 3 in Figure 2) are similar to highest elevations in the Short Pine Hills (at location 2) and in the Slim Buttes area (location 1), and to highest elevations along the Little Beaver Creek-Boxelder Creek drainage divide all of which stand 400 - 800 feet (122 - 244 meters) above the surrounding plains while the Powder River valley floor west of Figure 2 is more than 400 feet (122 meters) lower than the Little Beaver Creek valley floor. Deep erosion of the study region by southeast oriented ice-marginal melt water flow is not consistent with many previous interpretations. For example, Gill [8] interpreted landslide blocks located along what he determined to be deep northwest to southeast oriented valleys (consistent with deep erosion by southeast oriented flood flow) to have formed during late Oligocene or early Miocene time (not consistent with Pleistocene ages usually assigned to North American continental ice sheet advances). Clausen [9] associated rounded boulders and cobbles (consistent with floodwaters flowing across the region) with Oligocene sediments (not consistent with North American continental ice sheet ages), although he reported many Harding County rounded boulders and cobbles were not found in place. These previous interpretations pose an interesting dilemma.

The excellent geomorphic evidence described in this paper for massive southeast oriented ice-marginal melt water flood flow and for deep erosion of the Harding County and adjacent regions is in conflict with either usually assigned North American continental ice sheet ages or with the ages of Oligocene and Miocene sediments (found at several Harding County locations). One solution to this problem is the possibility that previous investigators misinterpreted ages of the mapped landslide blocks and of the rounded boulder and cobble deposition. Such a possibility would eliminate conflicts with ages assigned to Harding County Oligocene and Miocene sediments (e.g. Lillegraven [3] and Clark [4]). An alternate solution to the problem could be that a late Oligocene or early Miocene ice sheet deposited the coarse-grained glacial erratic material found south and west of the Missouri River valley (see Figure 1). Flint [16] noted that South Dakota glacial deposits found south and west of the Missouri River valley con- 
sisted only of coarse-grained erratic material, including large boulders, with no fine-grained till while north and east of the Missouri River valley he reported thick accumulations of fine-grained glacial till were present. He considered the possibility that glacial erratic materials to the south and west of the Missouri River had been deposited during an earlier glaciation, but rejected that hypothesis because weathering of erratic boulders and cobbles found to the south and west of the Missouri River was no more advanced than on boulders and cobbles found to the north and east of the Missouri River.

Even if the conflict between when the Oligocene and Miocene sediments were deposited and when the massive southeast oriented ice-marginal melt water floods occurred erosion of the Northern Great Plains region while deep north and northeast valleys eroded headward across southeast oriented ice-marginal melt water floods would still be inconsistent with many previous regional drainage history interpretations. For example Bluemle [17] argues that at least some segments of some river valleys discussed in this paper originated during preglacial time and were parts of a northeast oriented drainage network that flowed to the present day Hudson Bay region. While there has been no recently published original research related to northwest South Dakota erosional landforms or drainage route evolution Sears [18] in a widely distributed 2013 paper suggested that water from the Colorado River (in the Arizona Grand Canyon) may have flowed northward during the Oligocene-Miocene time period to reach the Hudson Bay region. His suggested hypothesis, without specifically addressing eastern Montana, northwest South Dakota, or southwest North Dakota evidence implies that all north and northeast oriented valleys discussed in this paper date back to at least that time.

The deep erosion of Northern Great Plains bedrock material by massive southeast oriented ice-marginal melt water floods reported in this paper is however consistent with evidence presented in a 1972 paper by William White [19] titled "Deep glacial erosion by continental ice sheets." In that paper White notes, "Glacial geologists have long regarded continental glaciers as ineffective agents of erosion. A common view is that the Laurentide and Fennoscandian ice sheets only removed regolith and smoothed bedrock... Denial of deep erosion also stems from many instances where ice sheets passed over incoherent, weak stuffs without removing them." Such incoherent, weak stuffs make up much of the Harding County and adjacent eastern Montana bedrock and of the bedrock in glaciated regions further to the north and east, yet numerous researchers have claimed they can trace north and northeast oriented pre-glacial valleys eroded in this incoherent, weak stuff across regions over which multiple continental ice sheets are hypothesized to have existed and over which the melt water from those ice sheets must have flowed. White's paper was strongly criticized by Sugden [20] and Gravenor [21] and has since been largely ignored. While this paper does not address the issue of ice sheet erosion it does present strong evidence in support of deep erosion by massive ice-marginal melt water floods. The unpublished Missouri River drainage basin landform origins research project notes (in 
the form of approximately 550 essays found in blog format at geomorphologyresearch.com) also strongly supports White's hypothesis for deep erosion by continental ice sheets as does all evidence presented in this paper. For those reasons the rejection of White's deep glacial erosion ideas by glacial geologists and regional geomorphologists was premature and further study of drainage route development and melt water erosion near continental ice sheet margin locations is recommended.

\section{References}

[1] Winchester, D.E., Hares, C.J., Russell, Lloyd, E.R. and Parks, E.M. (1916) The Lignite Field of Northwestern South Dakota. United States Geological Survey Bulletin, $627,169 \mathrm{p}$.

[2] Baker, C.L. (1952) Geology of Harding County. South Dakota Geological Survey Report of Investigation No. 68, Reprinted, But Not Revised in 1959, 36 p.

[3] Lillegraven, J.A. (1970) Stratigraphy, Structure, and Vertebrate Fossils of the Oligocene Brule Formation, Slim Buttes, Northwestern South Dakota. Geological Society of America Bulletin, 81, 831-850. https://doi.org/10.1130/0016-7606(1970)81[831:SSAVFO]2.0.CO;2

[4] Clark, J. (1975) Controls of Sedimentation and Provenance of Sediments in the Oligocene of the Central Rocky Mountains. In: Curtis, B.F., Ed., Cenozoic History of the Southern Rocky Mountains, Geological Society of America, Memoir, 144, 95-117. https://doi.org/10.1130/MEM144-p95

[5] Quirke, T.T. (1918) The Geology of the Killdeer Mountains, North Dakota. Journal of Geology, 26, 255-271. https://doi.org/10.1086/622588

[6] Toepelman, W.C. (1925) The Geology of a Portion of the Slim Buttes Region of Northwestern South Dakota, with Special Reference to Unusual Structural Features Due to Slumping. Unpublished $\mathrm{PhD}$ Thesis, University Chicago, Chicago.

[7] Malhotra, C.L. and Teglund, E.R. (1959) A New Tertiary Formation in Harding County, South Dakota. South Dakota Academy of Science, Proceedings, 38, 263 274.

[8] Gill, J.R. (1962) Tertiary Landslides, Northwestern South Dakota and Southeastern Montana. Geological Society of America Bulletin, 73, 725-735. https://doi.org/10.1130/0016-7606(1962)73[725:TLNSDA]2.0.CO;2

[9] Clausen, E. (1989) Presence of Rounded Boulders and Large Cobbles at Base of White River Group (Oligocene) Strata in Southwest North Dakota and Northwest South Dakota. Contributions to Geology, University of Wyoming, 27, 1-6.

[10] Clayton, L. (1980) Geologic map of North Dakota, North Dakota Geologic Survey.

[11] United States Geological Survey National Map Website. https://viewer.nationalmap.gov/advanced-viewer/

[12] United States Geological Survey Historical Map Collection Website. https://ngmdb.usgs.gov/topoview/viewer/\#4/39.98/-99.93

[13] Baker, V.R. (1981) Large-Scale Erosional and Depositional Features of the Channel Scabland. In: Baker, V.R., Ed., Catastrophic Flooding. The Origin of the Channeled Scabland, Dowden, Hutchinson and Ross, Inc., Stroudsburg, 276-310.

[14] Higgins, C.G. with Case Studies by Osterkamp, W.R. and Higgins, C.G. (1990) Seepage-Induced Cliff Recession and Regional Denudation. In: Higgins, C.G. and Coates, D.B., Eds., Groundwater Geomorphology: The Role of Subsurface Water in 
Earth-Surface Processes and Landforms, Geological Society of America Special Paper 252, 291-318.

[15] Clausen, E. (2017) Solving a Perplexing Scenic and Sage Creek Basin Drainage History Problem, Pennington County, South Dakota, USA. Journal of Geography and Geology, 9, 1-10. https://doi.org/10.5539/jgg.v9n2p1

[16] Flint, R.F. (1955) Pleistocene Geology of Eastern South Dakota. United States Geological Survey Professional Paper 262, 174 p.

[17] Bluemle, J.P. (1972) Pleistocene Drainage Development in North Dakota. Geological Society of America Bulletin, 83, 2189-2194. https://doi.org/10.1130/0016-7606(1972)83[2189:PDDIND]2.0.CO;2

[18] Sears, J.W. (2013) Late Oligocene-Early Miocene Grand Canyon: A Canadian Connection? GSA Today, 23, 4-10. https://doi.org/10.1130/GSATG178A.1

[19] White, W.A. (1972) Deep Erosion by Continental Ice Sheets. Geological Society of America Bulletin, 81, 1037-1056. https://doi.org/10.1130/0016-7606(1972)83[1037:DEBCIS]2.0.CO;2

[20] Sugden, D.E. (1976) A Case against Deep Erosion of Shields by Continental Ice Sheets. Geology, 4, 580-582.

https://doi.org/10.1130/0091-7613(1976)4<580:ACADEO>2.0.CO;2

[21] Gravenor, C.P. (1975) Erosion by Continental Ice Sheets. American Journal of Science, 275, 594-604. https://doi.org/10.2475/ajs.275.5.594

Submit or recommend next manuscript to SCIRP and we will provide best service for you:

Accepting pre-submission inquiries through Email, Facebook, LinkedIn, Twitter, etc. A wide selection of journals (inclusive of 9 subjects, more than 200 journals)

Providing 24-hour high-quality service

User-friendly online submission system

Fair and swift peer-review system

Efficient typesetting and proofreading procedure

Display of the result of downloads and visits, as well as the number of cited articles

Maximum dissemination of your research work

Submit your manuscript at: http://papersubmission.scirp.org/

Or contact ojg@scirp.org 